\title{
THE DIELEGTRIG PROPERTIES OF ANTARCTIC ICE
}

\author{
By W. J. Fitzgerald and J. G. Paren \\ (Department of Physics, University of Birmingham, Birmingham BI5 2TT, England)
}

\begin{abstract}
Two $0.5 \mathrm{~m}$ cores from "Byrd" station, Antarctica have been studied in the laboratory, one from a shallow depth $(155 \mathrm{~m})$ and the other from the zone where recrystallization has given a vertical $c$-axis fabric, and the air in situ is thought to be in clathrate form ( $1424 \mathrm{~m}$ ). The dielectric response has been studied in the frequency range $60 \mathrm{~Hz}$ to $10 \mathrm{kHz}$, and in the temperature range $-6^{\circ} \mathrm{C}$ to $-60^{\circ} \mathrm{C}$. The behaviour observed is markedly different from that of "pure" polycrystalline ice such as may be made by slowly freezing distilled de-ionized water and is thus at variance with the conclusions of Rogers (unpublished) who deduced, from measurements of the admittance of a dipole probe lowered through the fluid-filled drill hole at "Byrd", that the ice surrounding the hole had a dielectric response similar to that of "pure" ice. The Antarctic ice is shown to have properties similar to those of the ice from "Camp Century" and "Site 2" in Greenland studied by Paren (1973). In an attempt to discover what factors determine the difference in electrical behaviour between polar ice and pure ice, some samples were melted and subsequently refrozen slowly. Their dielectric response was similar to that of pure polycrystalline ice. These results are discussed in connection with the impurity content and growth conditions of the ices.
\end{abstract}

Résumé. Les propriétés diélectriques de la glace de l'Antarctique. Deux carottes de o,5 m provenant de la station "Byrd" dans l'Antarctique ont été étudiées en laboratoire. L'une provenait d'une faible profondeur $(155 \mathrm{~m})$ et l'autre d'une zone où la recristallisation a provoqué la formation de cristaux à axe- $c$ vertical et où l'air in situ est, pense-t-on, sous sa forme clathratique ( $1424 \mathrm{~m}$ ). La réponse diélectrique a été étudiée dans la gamme des $60 \mathrm{~Hz}$ à $10 \mathrm{kHz}$ et dans l'intervalle de température de $-6^{\circ} \mathrm{C}$ à $-60^{\circ} \mathrm{C}$. Le comportement observé est nettement différent de celui d'une glace polycristalline "pure" telle qu'on peut en fabriquer en congelant lentement de l'eau distillée dé-ionisée. Il y a donc désaccord avec les conclusions de Rogers (inédites) qui concluait, à partir de mesures de l'admittance d'une sonde bipole descendue dans un forage noyé à "Byrd", que la glace entourant le trou avait une réponse diélectrique semblable à celle d'une glace pure. On montre que la glace antarctique a des propriétés semblables à celles d'une glace provenant de "Century Camp" et de "Site 2" étudiée par Paren (1973) au Groenland. En vue de découvrir les facteurs qui déterminent la différence entre les comportements électriques de la glace polaire et de la glace pure, quelques échantillons furent fondus puis regelés lentement. Leur réponse diélectrique était semblable à celle de glaces polycristallines pures. On discute ces résultats selon la teneur en impuretés et les conditions d'édification des glaces.

Zusammenfassung. Die dielektrischen Eigenschaften antarktischen Eises. Zwei $0.5 \mathrm{~m}$ dicke Bohrkerne von der "Byrd" Station, Antarktika, wurden im Labor untersucht, einer aus geringer Tiefe (155 m), der andere aus der Zone, wo die Rekristallisation zur Ausbildung vertikaler $c$-Achsen geführt hat und die Luft in situ vermutlich in Klathratform enthalten ist ( $1424 \mathrm{~m}$ ). Die dielektrischen Reaktionen wurden im Frequenzbereich $60 \mathrm{~Hz}$ bis $10 \mathrm{kHz}$ bei Temperaturen zwischen $-6^{\circ} \mathrm{C}$ und $-60^{\circ} \mathrm{C}$ untersucht. Das beobachtete Verhalten ist wesentlich anders als das von "reinem" polykristallinem Eis, wie es beim langsamen Gefrieren von destilliertem, deionisiertem Wasser entsteht, und steht so im Widerspruch zu den Folgerungen ven Rogers (unveröffentlicht), der aus Messungen der scheinbaren Leitwerte einer Dipol-Sonde, die in das flüssigkeitsgefüllte Bohrloch an der "Byrd" Station abgesenkt wurde, schloss, dass das Eis in der Umgebung des Loches sich dielektrisch ähnlich verhält wie "reines" Eis. Das antarktische Eis hat sichtlich ähnliche Eigenschaften wie das Eis von "Camp Century" und "Site 2" in Grönland, das von Paren (r973) untersucht wurde. In einem Versuch zur Entdeckung der Faktoren, die den Unterschied im elektrischen Verhalten zwischen polarem Eis und reinem Eis bewirken, wurden einige Proben geschmolzen und anschliessend wieder langsam gefroren. Ihr dielektrisches Verhalten war ähnlich dem von reinem polykristallinem Eis. Diese Ergebnisse werden im Zusammenhang mit dem Gehalt an Verunreinigungen und den Wachstumsbedingungen der Eisproben diskutiert.

\section{INTRODUCTION}

Previous work has shown that the electrical properties of polar ice are completely different from those of "pure" ice (Paren, unpublished; Hochstein, 1967; Röthlisberger, I967). At first sight this is somewhat surprising, since the impurity content of polar ice is extremely low. Most of the impurities in the snow are also found in sea-water. Whereas Murozumi and others ( 1969 ) claimed that the impurities could be subdivided into dust and salts of marine origin, and when samples containing many years accumulation were analysed these marine salts were found in the same stoichiometric ratio as in sea-water, more recent experiments (Ragone and Finelli, 1972; Ragone and others, 1972), and indeed smaller sample volumes studied by Murozumi and others, have shown that in particular the cationic ratios in the snow do not 
follow those in sea-water. We know very little about the ionic balance in samples of such low impurity content, since there are difficulties in measurements of their anionic components.

The dielectric properties of ice formed from pure supercooled water droplets are known to be different from those of ice formed by slow freezing of large water volumes $\left(\approx \mathrm{IO}^{-3} \mathrm{~m}^{-3}\right)$. Whereas the electrical properties of ice droplets change markedly with the time elapsed since their nucleation at a low temperature (Evrard, 1973), the properties of ice formed reversibly by slow freezing at $0^{\circ} \mathrm{C}$ show by comparison only minor ageing effects. Since the polar ice is initially derived from supercooled water droplets in the atmosphere, the dielectric behaviour of ice from the polar regions may be determined not by impurity content but by the way in which the ice forms.

This paper describes a series of experiments conducted on a number of ice samples cut from two ice cores drilled from "Byrd" station, Antarctica: a shallow core from $155 \mathrm{~m}$ depth, and a deep core from I $424 \mathrm{~m}$ depth. Dielectric measurements were made at different temperatures in the frequency range $60 \mathrm{~Hz}$ to $10 \mathrm{kHz}$; since the attenuation of metre-length radio waves in polar ice sheets is determined primarily by the audio-frequency Debye dispersion (Evans, 1965; Paren, 1973) which falls in the frequency range studied here, the results obtained should be relevant to radio-echo sounding studies.

Recently, Rogers (unpublished; Rogers and Peden, 1973) has studied the electrical properties of ice in situ at "Byrd" station by lowering a dipole probe into the fluid-filled hole and measuring its input admittance. From the measurements he calculated the properties of the ice surrounding the drill hole by allowing for the contribution to the admittance from the fluids that are in contact with the probe, and he concludes that the audio-frequency dispersion of the surrounding ice is similar to that of pure ice at the same temperature.

\section{ExPERimental}

We used a General Radio i62oA Capacitance Measuring Assembly to measure accurately the direct capacitance between two elements each connected to the core of a co-axial cable. The Capacitance Measuring Assembly covers the frequency range $50 \mathrm{~Hz}$ to io $\mathrm{kHz}$, and we used three differently constructed brass cells with gold-plated electrodes having diameters $56 \mathrm{~mm}, 36 \mathrm{~mm}$, and $14 \mathrm{~mm}$ with guard electrodes. Ice samples ranging in thickness between $3 \mathrm{~mm}$ and $50 \mathrm{~mm}$ were studied. The thickest samples (thickness $t>20 \mathrm{~mm}$ ) were cut from the entire cross-section of the ice core using a hacksaw, and the ends were "freeze-tapped" to give flat faces using the method of Tobin and Itagaki (1970). The thinnest samples $(t<5 \mathrm{~mm})$ were melted to length and trimmed using a hot-wire cutter to a diameter slightly greater than that of the smallest cell. A similar procedure was carried out to prepare the samples for the $36 \mathrm{~mm}$ diameter cell. The ice samples were either frozen or pressed onto the electrodes of the cells and placed in a variable temperature enclosure. Temperatures between $-6^{\circ} \mathrm{C}$ and $-120^{\circ} \mathrm{C}$ could be reached, but we concentrated mainly on the range $-6^{\circ} \mathrm{C}$ to $-60^{\circ} \mathrm{C}$.

In order to derive the values of the relative permittivity and conductivity of the samples, the value of the air capacitance of the dielectric cell was required. For the smallest cell the ice could be melted leaving the electrode spacing unchanged and the air capacitance measured directly. As will be seen later, the absolute values of the permittivity and conductivity obtained for these smallest samples were consistent with each other. However, for the larger samples the air capacitance $C_{0}$ was calculated from the formula

$$
C_{0}=\epsilon_{0} A / t
$$

where $\epsilon_{0}$ is the electric constant, $A$ the measured electrode area, and $t$ the measured sample thickness. For the thickest samples there is a considerable spread in the values of the permittivity and conductivity observed. This is probably because the above formula is inapplicable 
when the width of the guard ring is significantly less than the thickness of a sample with a high relative permittivity.

The effect of melting and refreezing the polar samples was also investigated. The polar ice was placed in an air-tight cylinder made from "Perspex" (polymethylmethacrylate) of dimensions I $800 \mathrm{~mm}^{2} \times 20 \mathrm{~mm}$, and the ice melted. The "Perspex" container was then placed in a cold room at $-6^{\circ} \mathrm{C}$ to refreeze; the resulting ice appeared to have a similar bubble content to the ice from I 55 m depth at "Byrd". Dielectric tests were then carried out on these refrozen samples.
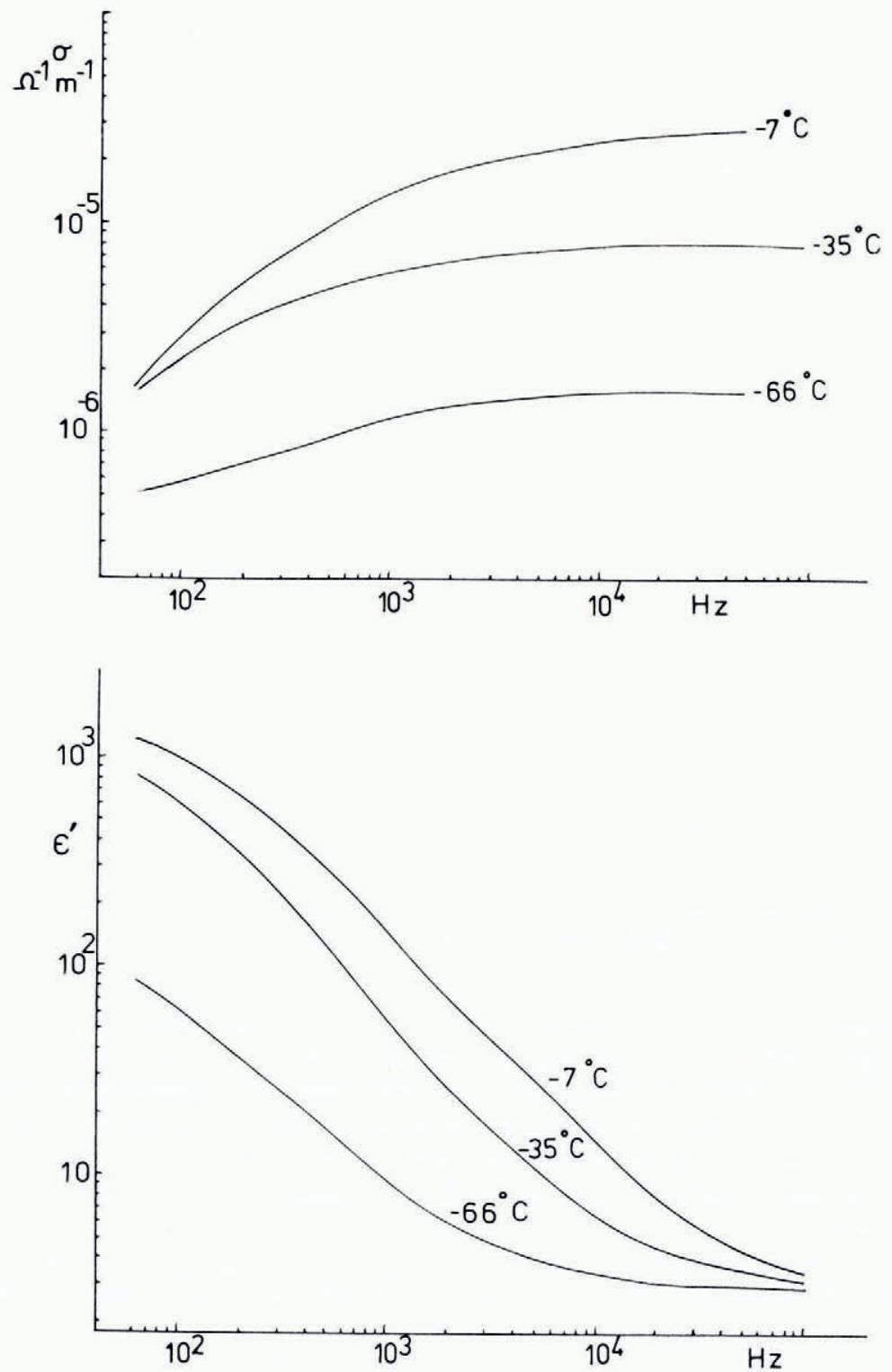

Fig. $I$. Frequency dependence of $(a)$ the conductivity $\sigma$ and $(b)$ the relative permittivity $\epsilon^{\prime}$ for several different temperatures. 


\section{Results}

Typical results are shown in Figure $\mathrm{I}$ for a thin sample of deep ice for which measurements to $100 \mathrm{kHz}$ were possible. It is seen that the conductivity is still increasing with frequency at Io $\mathrm{kHz}$, but tends to level off by $100 \mathrm{kHz}$. The relative permittivity reaches a limiting value $\epsilon_{\infty}$ at high frequencies (typically at $-60^{\circ} \mathrm{C}, \epsilon_{\infty}=3.13 \pm 0.02$ ), whilst at lower frequencies the value is far higher than the value of about go expected for the Debye dispersion of pure ice. Figure 2 shows the measured $10 \mathrm{kHz}$ conductivity $\left(\sigma_{10}\right)$ of this sample plotted logarithmically as a function of reciprocal temperature, and on the same graph are shown: the $\sigma_{100}$ values observed at $100 \mathrm{kHz}$ for ice from the Mendenhall Glacier which shows a similar dielectric response to "pure" ice, and the mean values for ice from "Camp Century" and "Site 2",

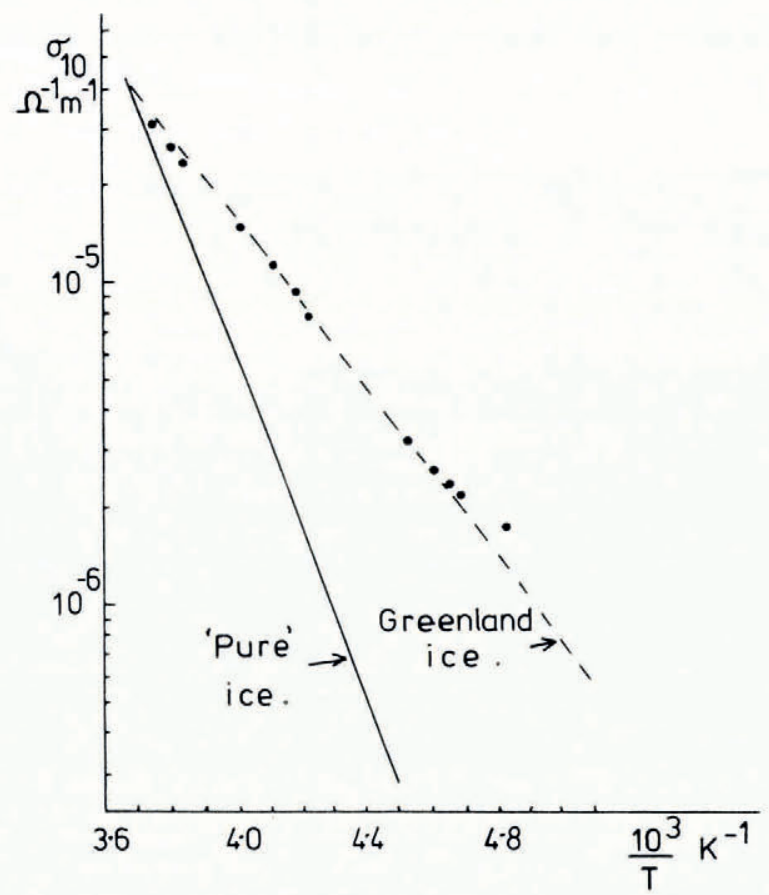

Fig. 2. Temperature dependence of the conductivity $\sigma_{10}$ for a "Byrd" sample. The continuous and dotted lines represent the results obtained by Paren (1973) for Mendenhall and Greenland ice respectively.

Greenland, observed by Paren (1973). Figure 3 is a similar plot for all fifteen samples, including ice from both $\mathrm{I} 55 \mathrm{~m}$ and I $424 \mathrm{~m}$, and, after corrections for air content, no difference in behaviour of the ice from the two depths was detectable. The spread in the values obtained may be attributed to the method used to get absolute values for the largest cell (as mentioned above). It is seen that the activation energy obtained from all the data points is comparable with, but slightly lower than, the value for ice from "Camp Century" and "Site 2", Greenland studied by Paren (1973).

At temperatures below about $-50^{\circ} \mathrm{C}$ the slope of the $\sigma_{10}$ graph changes slightly towards lower activation energies, but at higher temperatures the mean activation energy $E$ obtained by fitting

$$
\sigma=\sigma^{0} \exp \left\{-\frac{E}{R}\left(\frac{\mathrm{I}}{T}-\frac{\mathrm{I}}{T_{0}}\right)\right\}
$$


was found from the fifteen samples investigated to be $23.4 \pm 3.2 \mathrm{~kJ} \mathrm{~mol}^{-1}$ compared with $24.6 \pm \mathrm{I} . \mathrm{I} \mathrm{kJ} \mathrm{mol}{ }^{-1}$ for Greenland ice (Paren, 1973). The value obtained for $\sigma^{0}$, the conductivity at the melting temperature $T_{0}$, for the nine samples in the smallest cell was $(4.6 \pm 0.5) \times 10^{-5} \Omega^{-1} \mathrm{~m}^{-1}$ which may be compared to the values found at $100 \mathrm{kHz}$ for ten Greenland samples of $(4.50 \pm 0.22) \times 1^{-5} \Omega^{-1} \mathrm{~m}^{-1}$ and the value for Mendenhall ice of $4.4 \mathrm{I} \times \mathrm{IO}^{-5} \Omega^{-1} \mathrm{~m}^{-1}$. This apparent coincidence, which was first noticed in the Greenland samples by Paren (unpublished), is confirmed by our measurements.

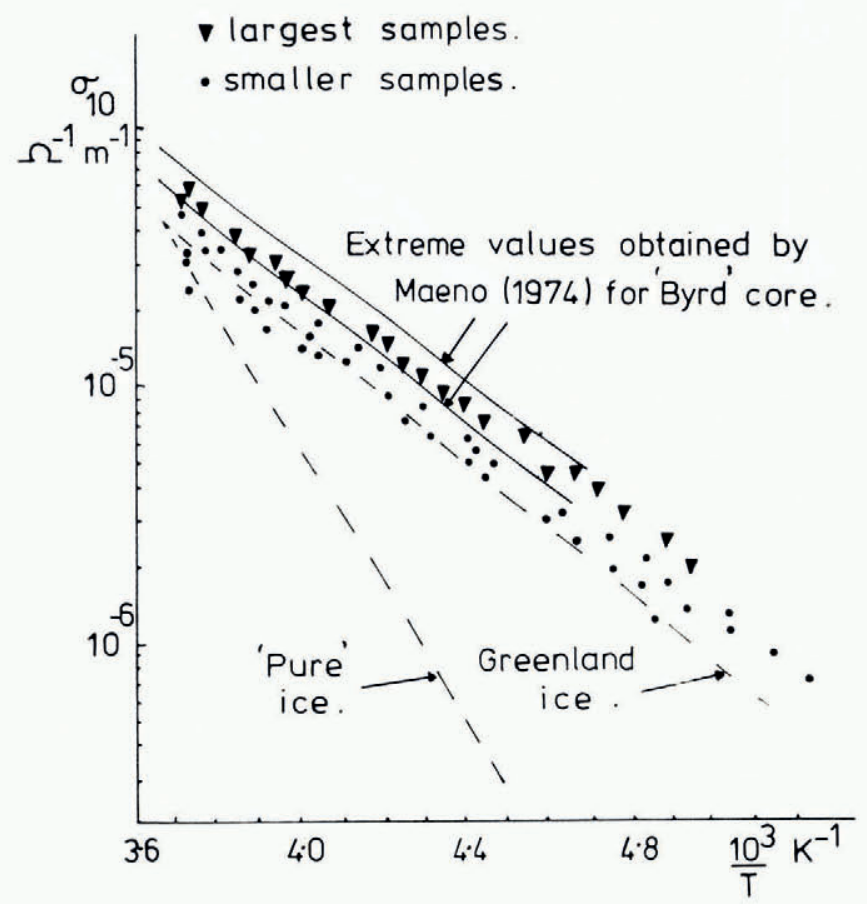

Fig. 3. Temperature dependence of the conductivities $\sigma_{10}$ for fifteen samples investigated.

Figure 4 shows some results obtained by melting and subsequently refreezing a typical "Byrd" sample, and comparison with Figure I shows that the results obtained are substantially different from those of the original samples. In fact the permittivity and conductivity for the refrozen samples strongly resemble those of "pure" ice. The low-frequency permittivity of the Debye dispersion has a value of around 9o, whilst the high-frequency permittivity $\epsilon_{\infty}=3.18 \pm 0.0 \mathrm{I}$ at $-50^{\circ} \mathrm{C}$. Figure 5 shows $\sigma_{\mathrm{I0}}$ for two samples logarithmically plotted as a function of reciprocal temperature, and there is a great similarity to the values for the highfrequency conductivity of "pure" ice. In fact, all the melted and refrozen samples behaved like ice very lightly doped with HF. According to Camplin and Glen (1973) the concentration of $\mathrm{HF}$ required to produce the same effect would be less than $5 \times 10^{-7} \mathrm{~mol} \mathrm{l}^{-1}$.

\section{Analysis of the audio-frequency dielectric dispersion}

In an attempt to analyse the results obtained in this experiment, a model capable of describing two relaxation processes in ice, a Debye dispersion (dispersion I) and a spacecharge dispersion (dispersion 2), was considered. Each dispersion was assumed to satisfy the Debye relaxation equations. The complex relative permittivity can then be written: 

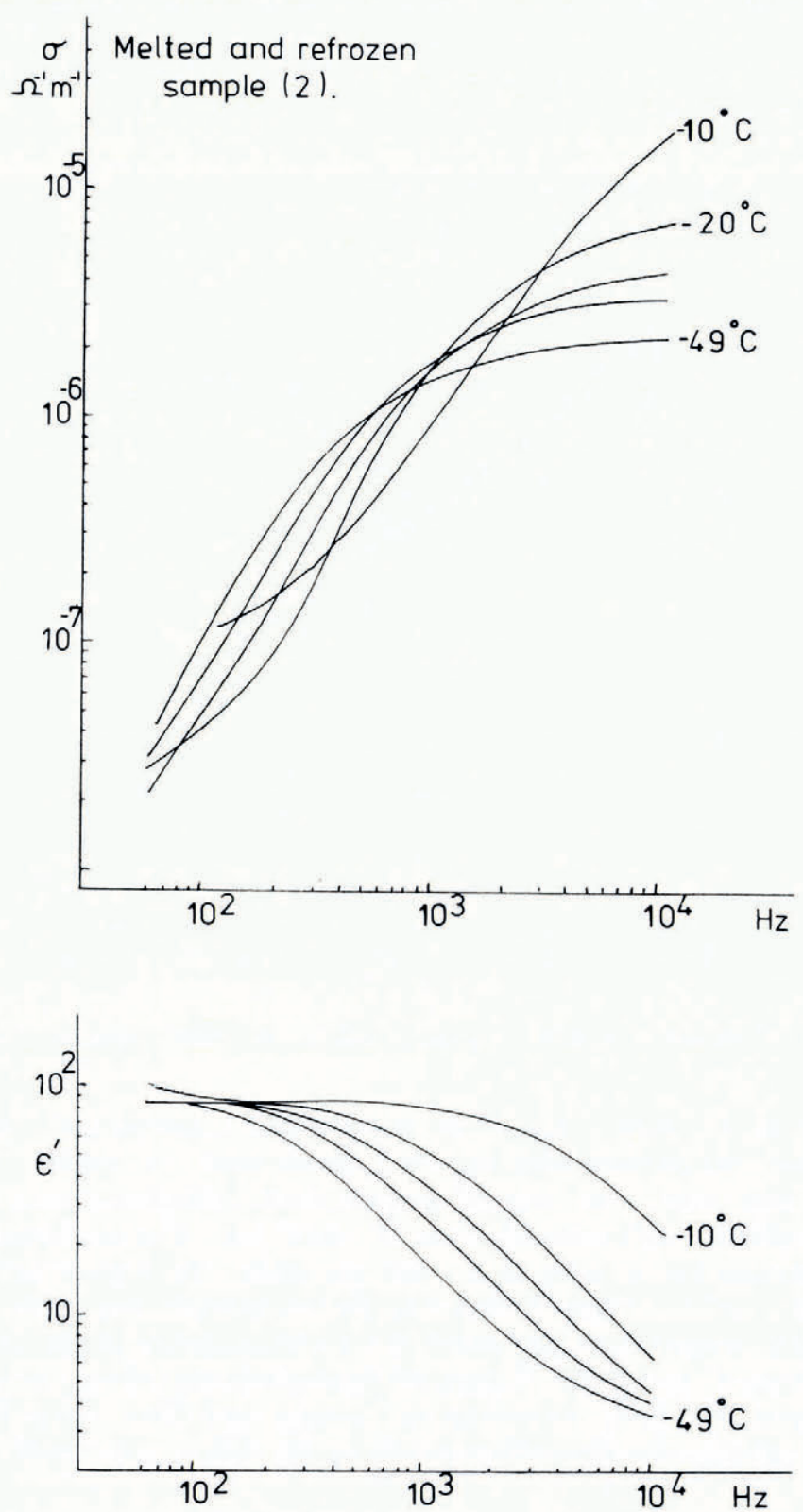

Fig. 4. Frequency dependence of the conductivity $\sigma$ and the dielectric permittivity $\epsilon^{\prime}$ at different temperatures for a melted and refrozen sample. 


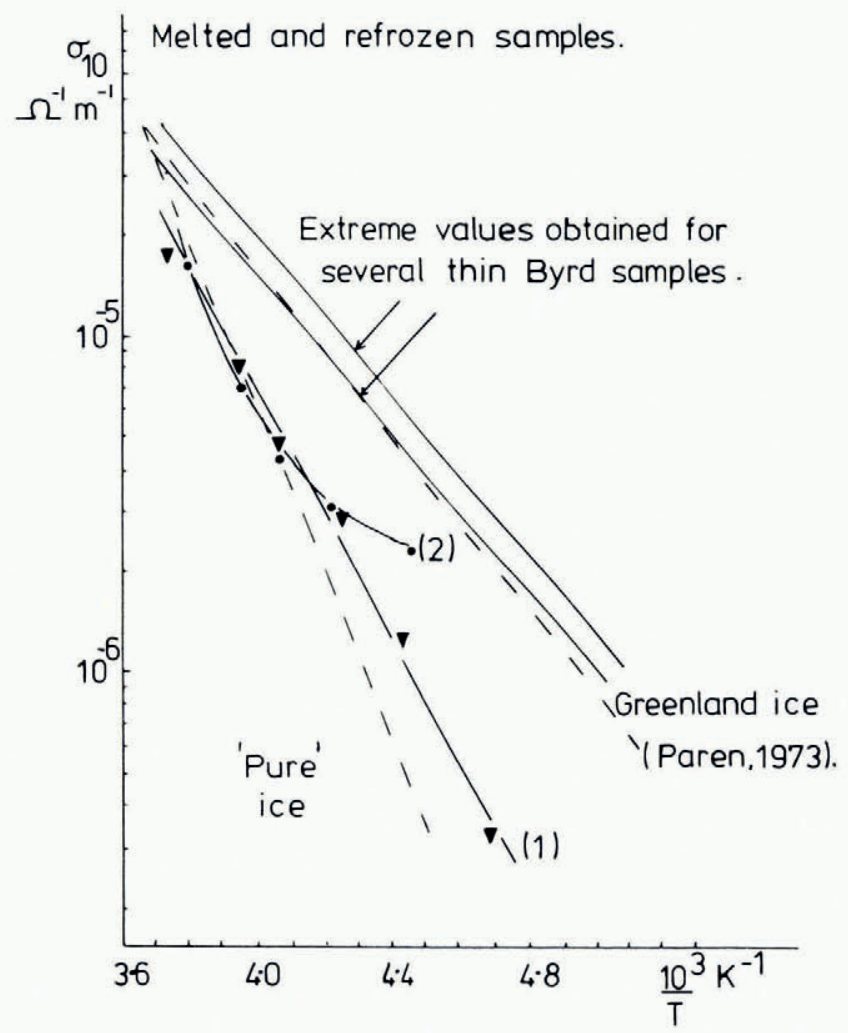

Fig. 5. Temperature dependence of the high-frequency conductivities $\sigma_{10}$ for two melted and refrozen samples.

$$
\epsilon^{\star}(\omega)=\epsilon_{\infty}+\frac{\Delta \epsilon_{1}}{\mathrm{I}+j \omega \tau_{1}}+\frac{\Delta \epsilon_{2}}{\mathrm{I}+j \omega \tau_{2}}
$$

where $\Delta \epsilon_{1}$ and $\Delta \epsilon_{2}$ are the dispersion strengths of dispersions I and $2, \tau_{i}$ is the relaxation time of the $i$ th dispersion and $\omega=2 \pi f$, where $f$ is the frequency. The conductivity change through each dispersion $\Delta \sigma_{i}$ is given by

$$
\Delta \sigma_{i}=\frac{\epsilon_{0} \Delta \epsilon_{i}}{\tau_{i}} .
$$

At high frequencies as the permittivity approaches $\epsilon_{\infty} \simeq 3.2$, the conductivity becomes independent of frequency $\left(\sigma_{\infty}\right)$. The low-frequency conductivity of the first dispersion $\sigma_{0}$ $\left(\sigma_{0} \equiv \sigma_{\infty}-\Delta \sigma_{1}\right)$ is, we believe, the true direct-current conductivity that would be observed in the absence of electrode effects which give rise to the space-charge dispersion.

The experimental data were fitted to this model using a least-squares iterative technique. It was observed that for the "Byrd" samples the d.c. conductivity $\sigma_{0}$ had the same activation energy as $\sigma_{\infty}$, and the value extrapolated to the melting point is given by $\sigma_{0}{ }^{0}=(2 . \mathrm{I} \pm 0.3) \times$ $\times \mathrm{IO}^{-5} \Omega^{-1} \mathrm{~m}^{-1}$, a value similar to that obtained for Greenland ice by Paren (1973). However, in general the fit to the experimental data was not particularly good (an error of $10 \%$ at $-40^{\circ} \mathrm{C}$ ) and in consequence another model was investigated to see if the fit to the data improved. 
Experiments by Watt and Maxwell (1960) on temperate glacier ice, by Fujino (1967) and Addison (1970) on sea ice and by Paren (unpublished) on firn in Axel Heiberg Island, Canada, have shown that a low-frequency behaviour given by

$$
\epsilon^{\prime \prime}=A f^{-m}
$$

is often experimentally observed. This behaviour is derived from an impedance $Z^{\star}$ given by

since

$$
z^{\star}=\zeta_{0}(j \omega)^{-(1-m)}
$$

$$
\epsilon_{z}^{\prime}=\frac{\omega^{-m}}{\zeta_{0}} \cos \left(\frac{m \pi}{2}\right) \quad \text { and } \quad \epsilon_{z}^{\prime \prime}=\frac{\omega^{-m}}{\zeta_{0}} \sin \left(\frac{m \pi}{2}\right) .
$$

A necessary consequence is that

$$
\tan \delta \equiv \frac{\epsilon_{z}^{\prime \prime}}{\epsilon_{z}^{\prime}}=\tan \left(\frac{m \pi}{2}\right)
$$

is independent of frequency in the range for which the model holds.

The experimental data were fitted to a model having a complex relative permittivity given by

$$
\epsilon^{\star}(\omega)=\epsilon_{\infty}+\frac{\Delta \epsilon_{\mathrm{I}}}{\mathrm{I}+j \omega \tau_{\mathrm{I}}}+\left(\epsilon_{z}^{\prime}-j \epsilon_{z}^{\prime \prime}\right)
$$

and the same least-squares procedure as before was used. The results of this computation gave a better fit to the data, (an error of $4 \%$ at $-40^{\circ} \mathrm{C}$ ). However, the calculations give the relaxation frequency $\left(f=\mathrm{I} / 2 \pi \tau_{\mathrm{I}}\right)$ of the first dispersion to be about $100 \mathrm{~Hz}$, which is surprisingly low and cannot be related to the Debye dispersion known in "pure" ice. The conductivity increases as a function of frequency with exponent $(\mathrm{I}-m)$, and the values obtained for $m$ were about 0.8 . Therefore in our experiments

$$
\sigma \propto f^{0.2}
$$

which implies that the value of the conductivity extrapolated to the $\mathrm{MHz}$ region is several times the value of the conductivity obtained at ro $\mathrm{kHz}$. However, the extrapolation far beyond the measured frequencies may not be justified.

Another model having a spread of relaxation times was also considered, in which the complex relative permittivity is given by

$$
\epsilon^{\star}(\omega)=\epsilon_{\infty}+\frac{\Delta \epsilon}{\mathrm{I}+(j \omega \tau)^{\mathrm{I}-\alpha}} .
$$

The computed fit to the experimental data using this model was good (an error of $\mathrm{I} \%$ at $-40^{\circ} \mathrm{C}$ ), and the conductivity at high frequencies derived from this model was again found to increase with frequency with exponent $\alpha$, which was typically 0.2 (Fitzgerald, unpublished).

The results obtained for the melted and refrozen samples were fitted to the first model having a Debye and space-charge dispersion and excellent fits were obtained (an error of $1 \%$ at $-40^{\circ} \mathrm{C}$ ). Good Cole-Cole semi-circles were obtained, and the computed fits closely resembled those expected for very lightly doped $\mathrm{HF}$ ice.

\section{Discussion}

It has been shown that the electrical behaviour observed in the ice from "Byrd" station is very similar to that observed for other polar samples, and is thus at variance with the measurements made in the "Byrd" drill hole by Rogers (unpublished; Rogers and Peden, I973). However, recently Von Hippel and others (1974) have shown that if ice samples doped with $\mathrm{HF}$ are contaminated by methanol vapour the effect of $\mathrm{F}^{-}$doping is essentially neutralized since methanol is an avid proton acceptor, and the ice behaves as "pure" ice. Since trichloroethylene is also a proton acceptor and is present in large amounts in the drill hole at "Byrd", the properties of the surrounding ice may have been modified. Melting and refreezing of the 
ice in the immediate neighbourhood of the hole due to the added ethylene glycol may also have modified these properties. It is of interest that the measurements of Rogers on the surface snow of density $0.4 \mathrm{Mg} \mathrm{m}^{-3}$ at "Byrd" at io and $12.8 \mathrm{kHz}$ (Webber and Peden, 1970; Peden and Rogers, I97I) are very similar to those measured on firn of density $0.43 \mathrm{Mg} \mathrm{m}^{-3}$ at $20 \mathrm{kHz}$ by Paren (unpublished) in Axel Heiberg Island. Glen and Paren (1975) have shown that the firn and snow measurements are in agreement with the deep polar ice samples after the effect of the air component in the snow has been accounted for.

The behaviour of pure ice has been explained by the presence of two types of defects, ionic and Bjerrum defects (Jaccard, 1959), which are thermally created in the pure ice lattice. The observation of higher conductivity in polar ice samples suggests that one or both of the electrical defects are more numerous in polar ice than in pure ice. Paren (unpublished, I973), showed that since the static conductivity was raised, the increase in conductivity was due to the ionic defects, and the presence of a zero activation energy for the ionic conductivity at high temperatures suggested that $\mathrm{H}_{3} \mathrm{O}^{+}$ions rather than $\mathrm{OH}^{-}$ions were responsible. The behaviour was very similar to that observed by Camplin and Glen (1973) for HF-doped ice containing approximately $\mathrm{IO}^{-5} \mathrm{~mol} \mathrm{l}^{-1}$. It is difficult to see how the necessary numbers of $\mathrm{H}_{3} \mathrm{O}^{+}$ions can be generated from the known impurity concentrations in polar samples if the impurities are salts stoichiometrically incorporated.

This view is strengthened by the measurements on the melted and refrozen samples, where the behaviour was similar to $\mathrm{HF}$-doped ice containing $5 \times \mathrm{IO}^{-7} \mathrm{~mol} \mathrm{l}^{-1}$. The $\mathrm{Cl}^{-}$concentration at "Byrd" is $2 \times \mathrm{IO}^{-6} \mathrm{~mol} \mathrm{l}^{-1}$, but the cations present would ensure that the resultant $\mathrm{H}_{3} \mathrm{O}^{+}$ion concentration would be less than that in ice derived from $\mathrm{HCl}_{\text {with }}$ the same $\mathrm{Cl}^{-}$ concentration (Paren, 1973). Even allowing for impurity rejection during refreezing and the loss of a few per cent of the sample volume during the mounting of the electrodes, it is difficult to reconcile the differences, unless the impurities are not equally effective in generating electrical defects in the two types of ice or the growth conditions of the original polar ice samples are what determine the electrical behaviour.

Recently, Evrard (1973) has studied ice emulsions that have been obtained by the nucleation of small supercooled water droplets at $-4 \mathrm{I}^{\circ} \mathrm{C}$. He observed that the dielectric behaviour changed with time when the ice emulsion was maintained at a constant temperature. The activation energy for the relaxation time was found to decrease discontinuously in jumps of $6.7 \mathrm{~kJ} \mathrm{~mol}^{-1}$, and the relaxation time extrapolated from lower temperatures always intersected the "pure" ice value at the melting point. During the course of his experiment the activation energy changed from about $48.1 \mathrm{~kJ} \mathrm{~mol}^{-1}$ to $22.4 \mathrm{~kJ} \mathrm{~mol}^{-1}$.

The high-frequency conductivity $\sigma_{\infty}$ obtained for the polar samples extrapolates back to the "pure" ice value near the melting point. This implies that it is possible that the mechanism for the observed behaviour in polar ice is similar to that responsible for the behaviour observed by Evrard (1973). He has shown that there is a unique relationship between the discrete temperatures at which supercooled water freezes spontaneously and the discrete spectrum of activation energies which are observed for the relaxation time in ice formed by the nucleation of supercooled water droplets. Brout (1965) and Schneider (I97I) suggest that the first-order transition involved in the freezing of water is preceded by co-operative effects within the liquid state, but the precise mechanism responsible for the evolution of the dielectric properties with time is, at present, unknown.

\section{Acknowledgements}

We would like to thank the Snow and Ice Branch of the U.S. Army Corps of Engineers Cold Regions Research and Engineering Laboratories (Dr C. C. Langway, Chief) which provided the two cores from "Byrd" station. One of us (W.J.F.) thanks the Natural Environment Research Council for a research studentship held during the course of this work under the supervision of Dr J. W. Glen to whom we also offer our thanks. 


\section{REFERENCES}

Addison J. R. ${ }^{1970 . ~ E l e c t r i c a l ~ r e l a x a t i o n ~ i n ~ s a l i n e ~ i c e . ~ J o u r n a l ~ o f ~ A p p l i e d ~ P h y s i c s, ~ V o l . ~ 41, ~ N o . ~} 1$, p. $54-63$.
Brout, R. ${ }^{1} 965$. Phase transitions. New York, W. A. Benjamin, Inc.

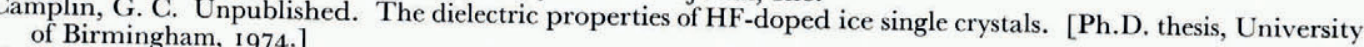

Camplin, G. C., and Glen, J. W. I973. The dielectric properties of HF-doped single crystals of ice. (In Whalley, E., and others, ed. Physics and chemistry of ice: papers presented at the Symposium on the Physics and Chemistry of Ice, held in Ottawa, Canada, I 4-18 August 1972. Edited by E. Whalley, S. F. Jones, L. W. Gold. Ottawa, Royal Society

Evans, S. 1965. Dielectric properties of ice and snow-a review. Fournal of Glaciology, Vol. 5, No. 42, p. 773-92. and others, ed. Physics and chemistry of Ottawa, Canada, I4-I8 August Canada, p. 199-203.)

Fitzgerald, W. J. Unpublished. The dielectric properties of Antarctic ice. [Ph.D. thesis, University of Birmingham, 1974.]

Fujino, K. ${ }^{1967}$. Kaihyō no yūdenteki seishitsu ni kansuru kenkyū [Dielectric properties of sea ice]. Teionkagaku: Low Temperature Science, Ser. A, [No.] 25, p. 127-69.

Glen, J. W., and Paren, J. G. 1975. Electrical properties of snow and ice. Journal of Glaciology, Vol. ${ }_{15}$, No. 73,

Hochstein, M. P. 1967. Electrical resistivity measurements on ice sheets. Fournal of Glaciology, Vol. 6, No. 47, Jaccard, C. 1959. Étude théorique et expérimentale des propriétés électriques de la glace. Helvetica Physica Acta,
Vol. 32, Fasc. 2, p. 89-1 28 .

Maeno, N. 1974. Investigations of electrical properties of deep ice cores obtained by drilling in Antarctica. (In Kyokuchihyō shōhyō no butsuriteki kagakuteki kenkyū [Physical and chemical studies on ices [sic] from glaciers and ice sheets]. Monbushō Kagaku Kenpi Sōgō Kenkyū (A). Hokokusho, [1973], p. 45-56.)

Murozumi, M., and others. I 969 . Chemical concentrations of pollutant lead aerosols, terrestrial dusts and sea salts in Greenland and Antarctic snow strata, [by] M. Murozumi, T. J. Chow and C. Patterson. Geochimica et Cosmochimica Acta, Vol. 33, No. 10, p. $1247-94$.

Paren, J. G. 1973. The electrical behavior of polar glaciers. (In Whalley, E., and others, ed. Physics and chemistry of ice: papers presented at the Symposium on the Physics and Chemistry of Ice, held in Ottawa, Canada, I4-18 August 1972. Edited by E. Whalley, S. F. Fones, L. W. Gold. Ottawa, Royal Society of Canada, p. 262-67.)

Paren, J. G. Unpublished. Dielectric properties of ice. [Ph.D. thesis, University of Cambridge, 1970.]

Peden, I. C., and Rogers, J. C. I97I. An experiment for determining the VLF permittivity of deep Antarctic ice. IEEE Transactions on Geoscience Electronics, Vol. GE-9, No. 4, p. 224-33.

Ragone, S. E., and Finelli, R. V. 1972. Cationic analysis of the Byrd station, Antarctica, ice core. U.S. Cold Regions Research and Engineering Laboratory. Special Report 180.

Ragone, S. E., and others. 1972. Cationic analysis of the Camp Century, Greenland, ice core, [by] S. E. Ragone, R. V. Finelli, S. Leung and C. Wolf. U.S. Cold Regions Research and Engineering Laboratory. Special Report I 79 .

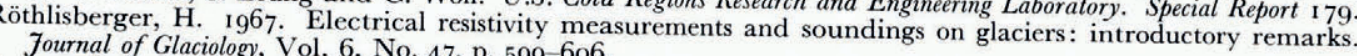
Journal of Glaciology, Vol. 6, No. 47, p. 599-6o6.

Rogers, J. C. Unpublished. A measurement technique for determining the VLF permittivity of deep Antarctic ice using a dipole probe. [Ph.D. thesis, University of Washington, Seattle, 1972 . University Microfilms order
no. 72-28655.]

Rogers, J. C., and Peden, I. C. 1973. VLF electrical properties of the ice sheet measured at Byrd station. Antarctic Journal of the United States, Vol. 8, No. 5, p. $24 \mathrm{I}-43$. Schneider, T. I971. Theory of the liquid-solid phase transitions. Physical Review A, Third Ser., Vol. 3, No. 6,
p. 21 $45^{-48}$.

Tobin, T. M., and Itagaki, K. 1970. A technique for producing strain-free flat surfaces on single crystals of ice. Fournal of Glaciology, Vol. 9, No. 57, p. 385-9o.

Von Hippel, A. R., and others. I 974 . Ions and dipoles in water and ice, and their transfer through the interface, by A. [R.V]on Hippel, R. Mykolajewycz, A. H. Runck and W. B. Westphal. Cambridge, Mass.: Massachusetts Institute of Technology, Laboratory for Insulation Research. (NIH Grant NIH-5-PoI-HLi4322-03, Technical Report I 4
(New Series).)

Watt, A. D., and Maxwell, E. L. I96o. Measured electrical properties of snow and glacial ice. Fournal of Research of the National Bureau of Standards (Washington, D.C.), Sect. D, Vol. 64, No. 4, p. 357-63.

Webber, G. E., and Peden, I. C. I970. VLF ground-based measurements in Antarctica: their relationship to stratifications in the subsurface terrain. Radio Science, Vol. 5 , No. 4, 1970, p. 655-62. 